\title{
Interpretación, conservación y divulgación de los valores fósiles del entorno de cabo Roche (Cádiz)
}

\begin{abstract}
SOLDECOCOS es una ONG especializada en desarrollo comunitario y gobernanza en espacios naturales y recursos marinos, cuyo marco de acción son las comunidades costeras y comarcas vinculadas al mar. Desde 2015, desarrolla junto a WWF España la iniciativa Seguimiento y mejora de pesquerías del Golfo de Cádiz, mediante procesos de gobernanza en zonas de alta productividad biológica, siendo el registro fósil de cabo Roche un lugar clave para su interpretación.
\end{abstract}

Jorge Sáez Jiménez | Sociedad para el Desarrollo de Las Comunidades Costeras (SOLDECOCOS)

URL de la contribución <www.iaph.es/revistaph/index.php/revistaph/article/view/4201>

Los acantilados de las calas de cabo Roche se encuentran al pie de la zona de especial conservación (ZEC) del pinar de Roche, espacio Red Natura 2000 protegido por el hábitat de interés comunitario 2270. Alberga una serie de especies amenazadas y endémicas de flora, como Thymus albicans (tomillo blanco), especie catalogada en peligro de extinción, y como especie más característica de la zona tenemos el Juniperus oxycedrus subsp. macrocarpa (enebro marítimo).

Sin embargo, el yacimiento fósil de alta singularidad de sus acantilados colindantes no se encuentra protegido de forma específica, más allá de formar parte del dominio público marítimo terrestre (DPMT). La interpretación de los recursos fósiles es de alta importancia para la divulgación del medio marino en la actualidad, así como para entender la evolución del espacio costero y la productividad de los ecosistemas marinos actuales.

En las paredes de estos accidentes geográficos altamente transitadas en épocas estivales, encontramos un registro fósil en buen estado de conservación del Plioceno, entre 3.000 y 5.000 millones de años (m.a.). En ellas se localizan tres unidades sedimentarias pertenecientes al Pleistoceno inferior o superior.

La base del acantilado está conformado por limos-arenas finas grisáceas con algunos restos de foraminíferos, como Globorotalia magaritae y Globigerina nepentes. Para facilitar la lectura cabe reseñar que los foraminíferos son animales de pequeño porte con una concha conformada por diversas cavidades que fosiliza con facilidad y forma parte de las arenas tanto submareales como intermareales.

La segunda unidad que encontramos pertenece a los depósitos calcoarenítas, bioclastos y arenas cementadas. Y la tercera unidad, que ocupa la mayor superficie visible de los acantilados pertenecientes a la submareal del Pleistoceno superior (3.000-3.500 m.a.) es una unidad de gran importancia para el estudio de la evolución y riqueza de los ecosistema marinos de este tramos del litoral debido a su abundancia de fósiles marinos predominando de forma clara las algas coralináceas que conforman los rodolitos, así como varios grupos de animales como son moluscos bivalvos, briozoos y equinodernos.

Dentro del grupo de los bivalvos encontramos de forma mayoritaria Pecten sp. y Ostrea edulis. De forma menos abundante se localizan Anomia ephippium y Pholas sp.

Los briozoos se asientan formando colonias generalmente sobre rodolitos. Este grupo de animales tapizan los distintos grupos de animales y vegetales sésiles (pegados al fondo marino) y se asientan en aguas limpias. Debido a sus lofóforos cavidades que les sirven para captar alimento (nutrientes de pequeñas partículas) su registro fósil se aprecia como puntos radialmente organizados de dentro hacia fuera.

En esta unidad, también podemos visualizar con facilidad fósiles de poliquetos formando estructuras propias 

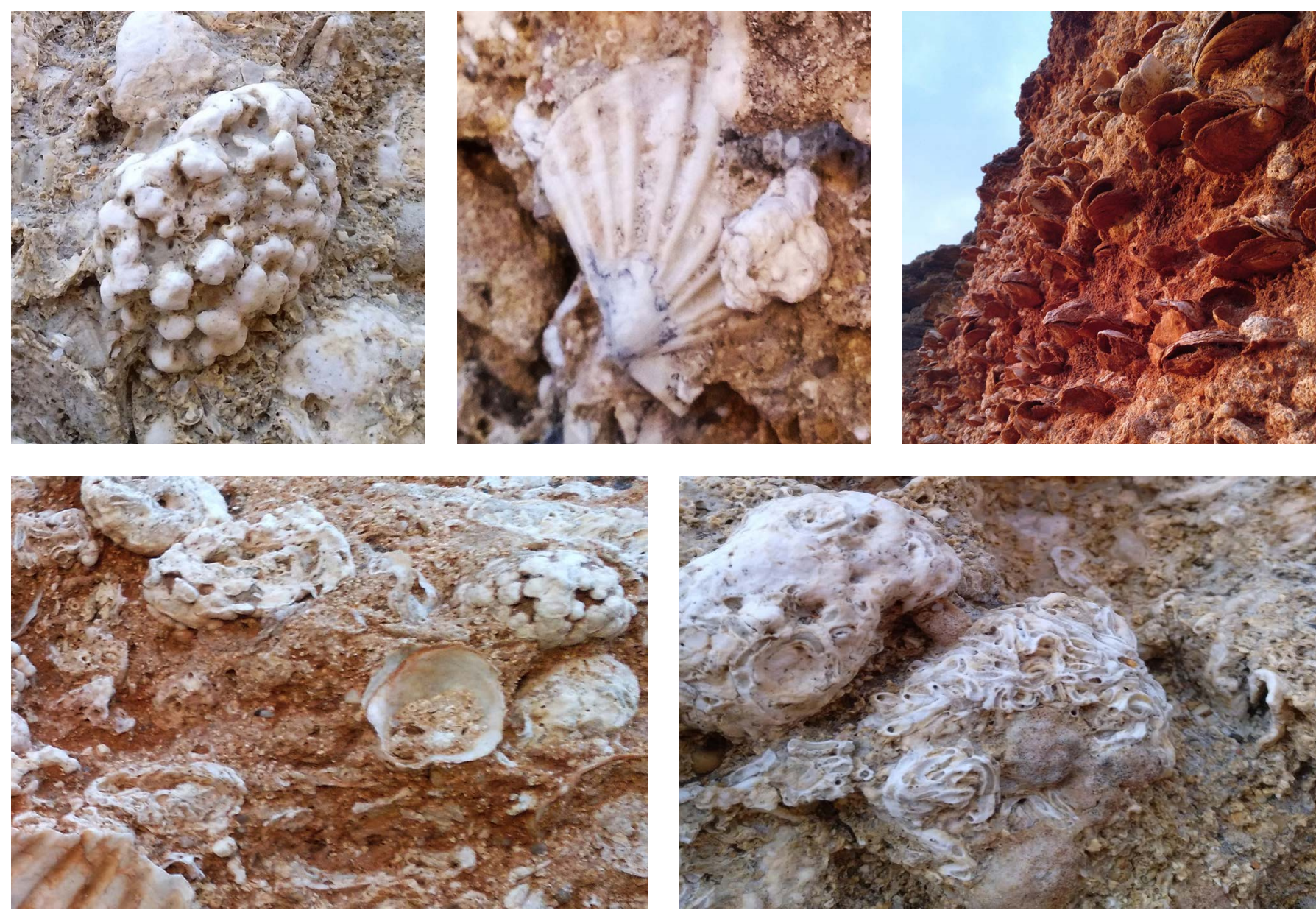

Imágenes de espacios fósiles del entorno de cabo Roche (Cádiz). De izquierda a derecha, de arriba a abajo: Rodolito; Pecten sp.; Ostrea edulis; Anomia ephippium; Estructuras generadas por los poliquetos (Polychaeta, annelida) | fotos Jorge Sáez Jiménez

o tapizando conchas de otros bivalvos. Estos animales pertenecen al filo animal de los anélidos.

Debido a la importancia para la divulgación de los distintos grupos de animales presentes en la zona, la potencialidad del espacio para la sensibilización ambiental y las necesidades de conservación del espacio, la Sociedad para el Desarrollo de Las Comunidades CosterasSOLDECOCOS se encuentra diseñando diversas iniciativas junto con las administraciones con competencia, así como con distintos agentes de interés para la interpretación, conservación y divulgación de los valores naturales del entorno de cabo Roche. Además actualmente SOLDECOCOS participa en un proyecto desarrollado por WWF España en colaboración con el sector pesquero, científicos y la propia administración estatal y autonómica. Se actúa sobre el área marina de cabo de Roche por la importancia de la zona para cubrir las carencias de red natura marina en la región biogeográfica marina atlántica en aguas españolas, siendo clave este espacio para garantizar la continuidad ecológica de la red natura marina al conectar los siguientes espacios: ZEC de la Breña y marismas del Barbate (ES6120008); LIC punta de Trafalgar (ES6120017); LIC fondos marinos de la bahía de Cádiz (ES6120009); LIC/ZEPA (ES0000140) de la bahía de Cádiz. El proyecto cuenta con el apoyo financiero del Fondo Europeo Marítimo Pesquero (FEMP), a través del programa PLEAMAR, de la Fundación Biodiversidad del Ministerio de Medio Ambiente, Pesca y Alimentación (MAPAMA). 